\title{
Reconstruction of the surface warming history of western interior Canada from borehole temperature profiles and other climate information
}

\author{
Jacek A. Majorowicz ${ }^{1, *}$, Walter R. Skinner ${ }^{2}$ \\ ${ }^{1}$ Northern Geothermal, 105 Carlson Close, Edmonton, Alberta T6R 2J8, Canada \\ ${ }^{2}$ Climate Research Branch, Environment Canada, Toronto, Ontario M3H 5T4, Canada
}

\begin{abstract}
Over the past several decades annual surface air temperature (SAT) warming in western interior Canada has been more than twice that of the global average. Inversions of the temperature profiles in boreholes throughout this large region provide evidence of anomalously high ground surface temperature (GST) warming trends between the mid-19th century and present. Previous studies have identified strong SAT/GST associations throughout this region for the 20th century. This analysis of the composite, century-scale, regional GST histories (GSTHs) is based on the deepest available borehole temperature logs from the Foreland Sedimentary Basin in western and northern Canada, east of the Cordillera. Although separated by almost $20^{\circ}$ latitude, there is strong regional correlation $(r=0.98)$ between the GSTHs developed from northern (boreal forest) and southern (prairie grassland) boreholes. When filtered, the GSTHs of western Canada correlate strongly with the northern hemisphere $(\mathrm{r}=0.80)$ and the Canadian Arctic $(\mathrm{r}=0.86)$ high temporal resolution proxy climate histories. Strong correlation also exists between the prairie grassland GSTH curve and the tree-ring-based surface summer temperature history from the Columbia Icefield in the Canadian Rocky Mountains close to Athabasca Glacier $(r=0.95)$. These findings strongly suggest that the similar, but enhanced, SAT warming signal identified by GSTHs makes western interior Canada a strong indicator region of global warming.
\end{abstract}

KEY WORDS: Surface air temperatures · Ground surface temperatures · Borehole temperature logs · Western Canada climate warming $\cdot$ Climate proxy data

\section{INTRODUCTION}

Do ground surface temperature (GST) changes from western interior Canada accurately represent recent climate in surrounding regions and in the northern hemisphere? Are GST histories (GSTHs) useful and credible when used to reconstruct decade-to-centuryscale climate variations from a large data-sparse region? This paper attempts to answer these questions by comparing GST data from western interior Canada with regional instrumental surface air temperature (SAT) records and other proxy-derived climatic histories.

*E-mail: majorowi@freenet.edmonton.ab.ca
The observed increase in globally averaged annual SAT over the past century, as measured at screen level ( $1.5 \mathrm{~m}$ above the ground surface), has been estimated to be between 0.3 and $0.6^{\circ} \mathrm{C}$ (Houghton et al. 1996). The temperature increase has been neither spatially nor temporally uniform. Some regions have warmed, while other regions have shown little change, or have even cooled. Fig. 1 shows the annual SAT trends from 1950 to 1995 for Canada (Zhang et al. 2000). Western and Northwestern regions of the country show amplified warming ranging from 0.5 to $2.0^{\circ} \mathrm{C}$, while northeastern regions have cooled by a similar magnitude. Also, considerably less warming, and even cooling, has occurred over the North Atlantic and North Pacific, and oceanic margins of the 


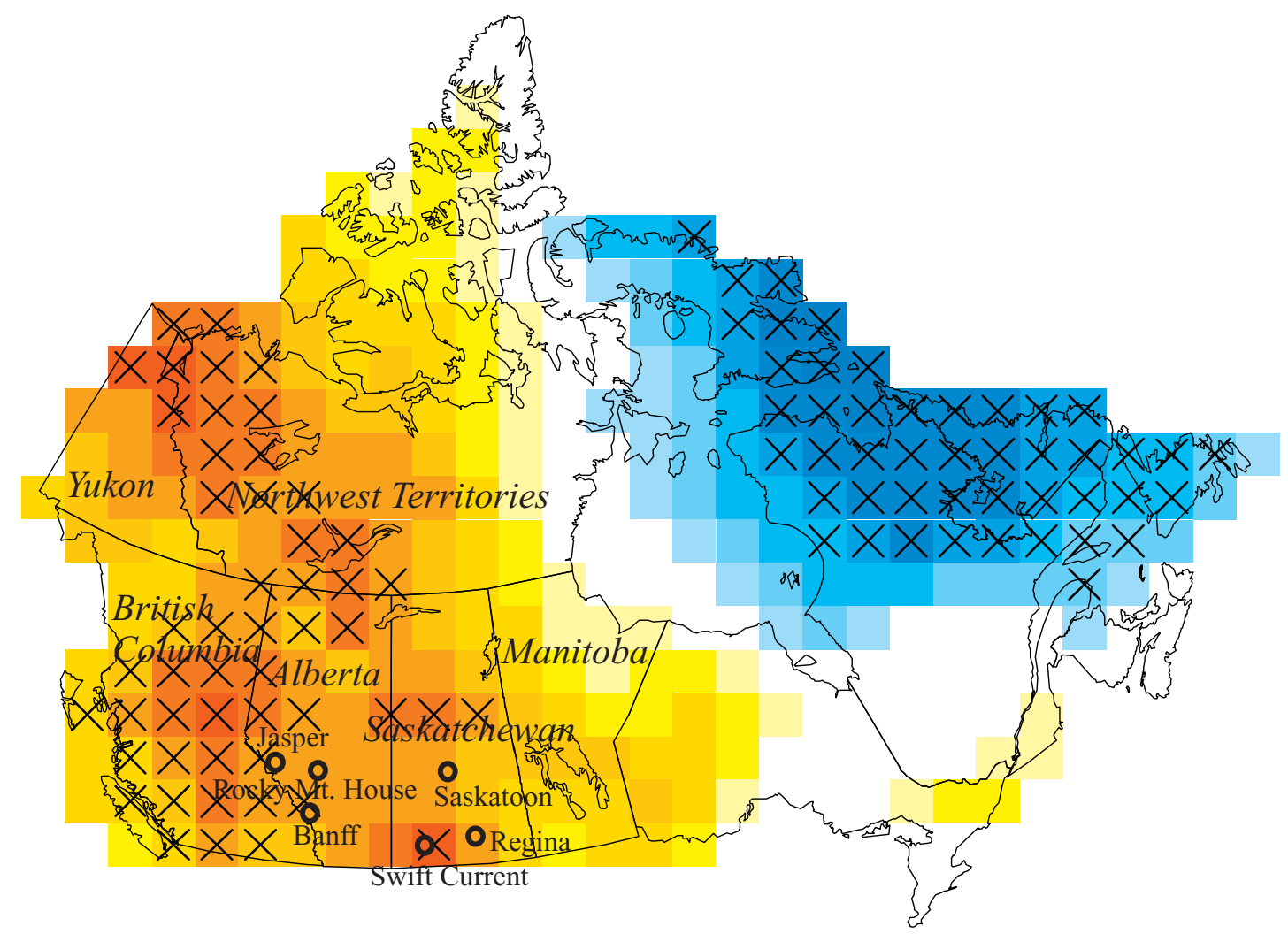

\section{Annual SAT \\ Trend ${ }^{\circ} \mathrm{C}$}

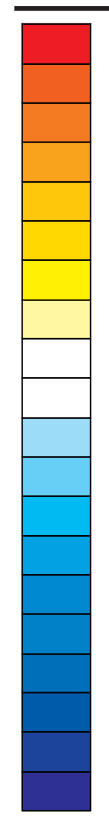

Fig. 1. Annual surface air temperature (SAT) trend, 1950 to 1995. Crosses denote statistically significant change

North American continent (IPCC 1996). Most of the SAT warming has occurred during winter and spring in the continental interior.

The greater warming of the continental interiors may be due both to the moderating effect of the oceans on the coastal margins and to positive feedbacks related to the hydrologic cycle, including the timing of freezing and melting and changes in the areal distribution of ice and snow on land. Also, Canada is located entirely in mid- to high latitudes, where interannual and longer-term variations in atmospheric circulation patterns can have considerable effect on regional climate. A persistent change in the normal jet stream track will affect temperatures differently in various regions of the country by changing the relative frequency of their exposure to warm and cold air masses.

Forward modelling (Lachenbruch \& Marshall 1986) and the functional space inversion (FSI) techniques (Shen \& Beck 1991, Pollack et al. 1996, Shen et al. 1996) applied to precise temperature logs varying in maximum depth from 80 to $500 \mathrm{~m}$ in 80 boreholes in the Canadian Prairie Provinces (mostly in Alberta and Saskatchewan (Majorowicz 1993, Majorowicz \& Skinner 1997a,b, Majorowicz \& Safanda 1998a,b, 2001, Majorowicz et al. 1999) have provided evidence of high GST warming $\left(1.9^{\circ} \mathrm{C}, \mathrm{SD}=0.7\right)$ in the 20th century.
This anomalous warming is through a large region covering almost $20^{\circ}$ latitude (Majorowicz \& Skinner 1997a, Skinner \& Majorowicz 1999). Further analysis of GSTHs from temperature logs from 35 selected deep boreholes (>130 $\mathrm{m}$ in depth) in Northwest Territories and Alberta (Majorowicz \& Safanda 1998a, 2001) and additional detailed analysis of 8 boreholes in the southeastern Prairie Provinces of Saskatchewan and Manitoba (Majorowicz et al. 1999) has shown that the onset of this large warming starts at the end of the previous century with largest warming in the 20th century. This large magnitude of GST warming in Western Canada is confirmed by temperature anomalies from borehole temperature profiles measured in southwestern Manitoba and North Dakota (Gosnold et al. 1997). Similar evidence of GST warming following a cold period with its minimum GST in the early to mid-19th century has been found from boreholes across northern North America: Quebec and Ontario (Beltrami et al. 1992, Wang et al. 1992), the midwestern United States (Harris \& Chapman 1998), Manitoba (Guillou-Frottier et al. 1998), and the Canadian Arctic (Beltrami \& Taylor 1995).

Large changes in GST in the Western Canadian Foreland basin are in contrast to small precipitation changes for the same time period and same area 
(Zhang et al. 1999). It was hypothesized (Majorowicz \& Skinner 1997b) that this large-magnitude GST warming, which is the highest in Canada and one of the highest in the northern hemisphere, could lead to land surface drying, enhance surface warming and cause even greater regional climatic warming (feedback effect). This has, in part, been caused by permanent land-cover changes in this century, resulting in changes in the moisture balance (Majorowicz \& Skinner 1997b, Lewis \& Wang 1998, Skinner \& Majorowicz 1999).

Spatial patterns of SAT and GST warming for the period 1900 to 1990 over midwestern and northern North America have been compared (Skinner \& Majorowicz 1999). There has been a 20th-century SAT warming at screen level $(1.5 \mathrm{~m})$ of between 0.5 and $1.0^{\circ} \mathrm{C}$ throughout most of the Great Plains of the United States into the southern Prairies Provinces and from 1.0 to $2.0^{\circ} \mathrm{C}$ in northern Alberta and southern Northwest Territories. There has been 20th-century GST warming at the ground surface of greater than $1.5^{\circ} \mathrm{C}$ in the southern Prairie Provinces and of greater than $2.0^{\circ} \mathrm{C}$ in northern Alberta and southern Northwest Territories. A comparison of the SAT and GST warming maps identifies the regions of anomalous SAT warming $(0.5$ to $\left.1.5^{\circ} \mathrm{C}\right)$ and GST warming $\left(1.5\right.$ to $\left.3^{\circ} \mathrm{C}\right)$ to be spatially coherent. Anomalous SAT and GST warming extend from Northwestern Canada (Northwest Territories), through the Canadian Prairie Provinces, and into the northwestern plains of the United States (North Dakota, Montana). Statistically significant spatial correlation exists between the SAT and GST warming patterns characterized $(\mathrm{r}=0.70)$, indicating that variations in SAT are the primary factor causing variations in GST. Even though similar spatial patterns of warming have occurred, the GST warming is approximately $35 \%$ larger than the SAT warming $\left(1.9\right.$ vs $\left.1.1^{\circ} \mathrm{C}\right)$. The reasons for the difference between the GST warming and SAT warming have been discussed, and land surface clearing (from boreal forest to farming and grazing systems) and resultant land drying in the vicinity of the borehole sites were considered to be possible causes of step-like temperature change at various times in the 20th century (Majorowicz \& Skinner 1997a,b, Skinner \& Majorowicz 1999).

Instrumental SAT histories and proxy-based SAT reconstructions (mainly tree-ring studies and lacustrine oxygen isotope, sedimentation, or grain size studies) exist for the Canadian Arctic, Alberta foothills and lowlands and the northern hemisphere (Beltrami \& Taylor 1995, Luckman et al. 1997, Overpeck et al. 1997, Campbell et al. 1998, Mann et al. 1998). It is commonly believed in the climate research community that climate reconstruction using tree rings provides finer temporal resolution than GSTHs derived from bore- hole temperatures. In many cases tree-ring data are standardized to remove growth trends, usually with arbitrary functions. These functions are different for each single tree used to create the chronology. Such detrending filters can remove most of the long-term climatic information, especially when data from many sources are compiled (Mann et al. 1998, Mann \& Bradley 1999). Tree-ring data calibration versus SAT relies strongly on the assumption that they are temperature sensitive through the history of their growth. On the other hand, GSTHs provide direct measurement of the GST change and are thus more closely related to current climatological observations than are other proxies. They are free of any uncertainties due to conversion from proxy data to temperatures.

\section{DATA}

\subsection{Borehole temperature data}

Over 50 precise temperature logs (measurement precision: 0.01 to $0.03^{\circ} \mathrm{C}$ ) from deep boreholes logged at 43 borehole sites in Alberta, Saskatchewan and Manitoba (Majorowicz 1993, Majorowicz \& Safanda 1988a, Gosnold et al. 1997, Majorowicz et al. 1999, A. M. Jessop pers. comm. 1998) and in the Northwest Territories and Yukon (Taylor et al. 1982) were available. The deepest boreholes were selected for the analysis $(150$ to $500 \mathrm{~m})$. The other shallower depth measurements all show evidence of warming in recent decades; however, they were not considered here due to difficulty in establishing the geothermal gradient. The borehole logs are shown in Majorowicz \& Safanda (1998) and Majorowicz et al. (1999). Here we give general information about location, depth and type of terrain (Table 1). Transient components of temperaturedepth profiles calculated by simultaneous inversion have been shown elsewhere (Majorowicz \& Safanda 2001). The location of the boreholes and the study area is shown in Fig. 2 with the contour map of the GST warming magnitude in this century.

Most of the boreholes in Alberta, Saskatchewan and Manitoba were logged between 1992 and 1995. The boreholes in the Northwest Territories and Yukon were logged in the 1980s by the Earth Physics Branch of Energy Mines Resources, Ottawa, Canada (Taylor et al. 1982). One borehole in southern Saskatchewan was logged by the University of North Dakota geothermal group (Gosnold et al. 1997). All temperature logs were made using portable logging equipment with 500 to $1000 \mathrm{~m}$ of cable and a thermistor probe described by Jessop (1990). The majority of the boreholes are located in Alberta and Saskatchewan, with half located in the boreal forest to the north and the other 
Table 1. Description of the borehole sites with temperature logs used in this study

\begin{tabular}{|c|c|c|c|c|c|}
\hline No. & Borehole & $\begin{array}{l}\text { Lat. } \\
\left({ }^{\circ} \mathrm{N}\right)\end{array}$ & $\begin{array}{l}\text { Long. } \\
\left({ }^{\circ} \mathrm{W}\right)\end{array}$ & $\begin{array}{c}\text { Depth } \\
\text { (m) }\end{array}$ & Terrain \\
\hline 1 & N89H13 & 68.37 & 135.55 & 536 & Tundra \\
\hline 2 & N296 & 63.15 & 130.26 & 188 & Boreal \\
\hline 3 & N297-2 & 60.353 & 127.397 & 192 & Boreal \\
\hline 4 & N297-3 & 60.355 & 127.397 & 270 & Boreal \\
\hline 5 & N295 & 59.85 & 117.89 & 835 & Boreal \\
\hline 6 & TFM2 & 57.39 & 111.82 & 123 & Boreal \\
\hline 7 & TFM1 & 57.33 & 111.69 & 254 & Boreal \\
\hline 8 & TFM15a & 56.77 & 112.49 & 298 & Boreal \\
\hline 9 & TPR2 & 55.61 & 116.68 & 211 & Boreal \\
\hline 10 & T963 & 55.39 & 111.13 & 197 & Boreal \\
\hline 11 & T962 & 55.35 & 111.04 & 229 & Boreal \\
\hline 12 & TCL944 & 54.65 & 110.51 & 166 & Boreal \\
\hline 13 & TCL94 & 54.62 & 110.43 & 130 & Boreal \\
\hline 14 & TCL1 & 54.61 & 110.25 & 132 & Boreal \\
\hline 15 & TCL14 & 54.57 & 110.81 & 147 & Boreal \\
\hline 16 & TCL10 & 54.48 & 110.62 & 134 & Boreal \\
\hline 17 & TS941 & 54.45 & 109.87 & 120 & Boreal \\
\hline 18 & TCL4 & 54.06 & 110.41 & 131 & Boreal \\
\hline 19 & TCL5 & 54.06 & 110.41 & 131 & Boreal \\
\hline 20 & TCL3 & 54.06 & 110.41 & 195 & Boreal \\
\hline 21 & T961 & 54.01 & 113.18 & 177 & Boreal \\
\hline 22 & Т790 & 53.91 & 114.11 & 130 & Boreal \\
\hline 23 & T765 & 53.35 & 110.01 & 163 & Boreal \\
\hline 24 & T791 & 53.16 & 110.98 & 125 & Boreal \\
\hline 25 & T651 & 53.11 & 114.23 & 244 & Grass \\
\hline 26 & T965 & 53.06 & 103.95 & 151 & Grass \\
\hline 27 & T754 & 52.72 & 110.85 & 131 & Grass \\
\hline 28 & TSA1 & 52.41 & 110.59 & 129 & Grass \\
\hline 29 & T964 & 52.26 & 105.52 & 178 & Grass \\
\hline 30 & $\mathrm{~T} 779$ & 52.09 & 110.85 & 215 & Grass \\
\hline 31 & T966 & 52.02 & 107.12 & 530 & Grass \\
\hline 32 & T967 & 52.01 & 107.11 & 529 & Grass \\
\hline 33 & TSA3 & 51.57 & 110.48 & 120 & Grass \\
\hline 34 & Riverhurst9c & 50.95 & 107.00 & 243 & Grass \\
\hline 35 & Riverhurst1c & 50.92 & 106.96 & 230 & Grass \\
\hline 36 & Riverhurst5b & 50.90 & 106.917 & 164 & Grass \\
\hline 37 & Riverhurst8c & 50.88 & 106.87 & 236 & Grass \\
\hline 38 & TSA6 & 49.38 & 112.21 & 123 & Grass \\
\hline 39 & TSA10a & 49.18 & 111.06 & 232 & Grass \\
\hline 40 & TSA10b & 49.18 & 111.06 & 232 & Grass \\
\hline 41 & TKT1 & 49.07 & 106.25 & 150 & Grass \\
\hline 42 & TSA12 & 49.22 & 111.36 & 166 & Grass \\
\hline 43 & TSA13 & 49.01 & 111.32 & 123 & Grass \\
\hline
\end{tabular}

half in the grassland/aspen parkland to the south. The boreholes were drilled between 1970 and 1990 and were left undisturbed by any drilling operations since then. There was no evidence of water flow in boreholes and outside the casing (Majorowicz 1993). In the majority of cases temperature versus depth profiles are the result of a single log in one borehole over a depth range from the water table level to the bottom of the borehole. In a few cases, however, the temperature profile consists of the measurements in 2 boreholes at 1 site (boreholes $<100 \mathrm{~m}$ apart). The boreholes are located in a variety of terrains (Table 1).

\subsection{SAT data}

The historical SAT time series used (see Fig. 1 for station locations) for the comparison Rocky Mountain foothill and prairie grassland changes were taken from the Canadian historical climate network (HCN) database (Vincent 1998, Vincent \& Gullett 2001).

Historical SAT data (Fig. 1) represent measurements originally made at airports, agricultural stations and rural volunteer sites. Instrument compounds are located over grassed surfaces in order to maintain national observation consistency. Changes in the immediate vicinity of the instruments have been considered and adjustments have been made to ensure time series homogeneity. In general, the surface characteristics immediately surrounding the instruments are not representative of the larger regional landscape characteristics that the temperature series are designed to represent, especially in forested regions. On the other hand, GST data have different site observational characteristics. They are located in natural areas where permanent or temporary land-cover changes have occurred in this century (see Fig. 2 for site locations).

\section{THE INVERSION METHOD}

The individual GSTHs were obtained by applying the FSI technique (Shen \& Beck 1991, Beltrami et al. 1992, Wang et al. 1992, Shen et al. 1995a, Pollack et al. 1998), and a detailed description is given in Majorowicz \& Safanda (1998a,b, 2001) and Majorowicz et al. (1999). This technique assumes that heat transfer is by conduction alone through a 1-dimensional, possibly heterogeneous medium. Using Shen et al.'s (1995a) FSI inversion method, a GSTH reconstruction is sensitive to relative constraints on the a priori conductivity model, physical properties, and temperature measurements. A GSTH reconstruction is the goal of inversion. Due to the lack of sample rock chips, and therefore a complete lack of measured conductivities from Alberta and Saskatchewan boreholes, the thermal conductivity was estimated from lithology, porosity and typical average thermal conductivity of sedimentary rocks in the region (Beach et al. 1987). Low thermal conductivity of clastic rock types (mainly shales, siltstones, mudstones, clays, etc.) is the cause of very low effective thermal conductivity (1.4 to $1.6 \mathrm{~W} \mathrm{mK}^{-1}$ ) and low diffusivity $\left(0.6\right.$ to $\left.0.8 \times 10^{-6} \mathrm{~m}^{2} \mathrm{~s}^{-1}\right)$ observed here. Such low diffusivity values allow us to look for GST events relatively far back in time (a few centuries) with borehole temperature logs shallower than those from crystalline rocks in the Canadian Shield (Beltrami et al. 1992). The temperature profiles were subjected to the inversion described by Shen et al. (1995a). Several versions were 


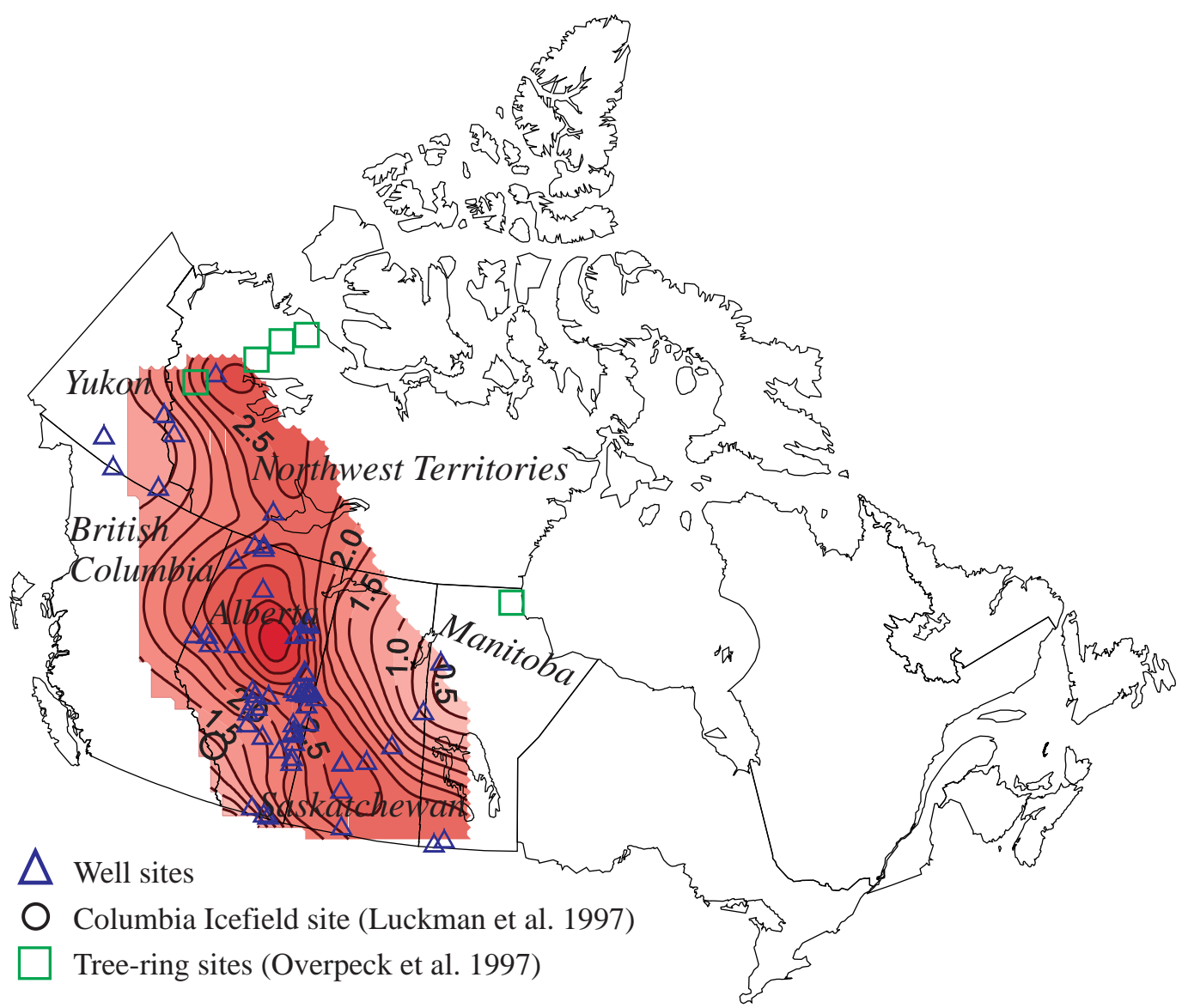

Annual GST Trend ${ }^{\circ} \mathrm{C}$

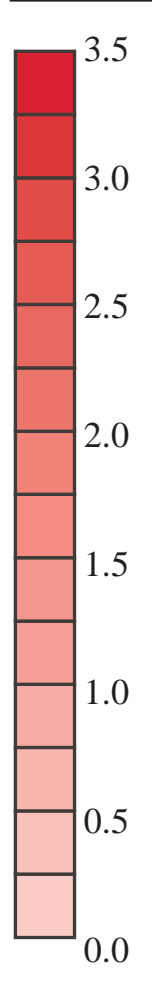

Fig. 2. Study area and locations of boreholes in the Foreland Western and Northwestern Canadian Sedimentary Basin. The annual ground surface temperature (GST) trend, 1900 to 1990, is also shown

considered (Majorowicz \& Safanda 1998a,b, 2001, Majorowicz et al. 1999).

Fig. 3 shows examples of GSTHs from individual inversions for 2 large and 1 small area with multiple borehole logs; the large areals include boreal forest sites from the Cold Lake Alberta/Saskatchewan border area (Fig. 3a) and prairie grassland sites from the Riverhurst area in southern Saskatchewan (Fig. 3b). It can be seen that variations in GSTH exist even for the relatively small areas and averaging of the result is needed. There is a risk of misinterpretation of the GSTH by inversion of the single logs with tight constraints on the borehole data (see Beltrami et al. 1992, Shen et al. 1996, Pollack et al. 1996 for a discussion of the averaging and simultaneous inversion of the individual borehole temperature logs).

\section{COMPOSITE GSTHs}

An averaging procedure was applied to obtain combined standardized GSTH curves representing large regions. Fig. 4 shows a comparison of the global 4-region composite GSTH curve (C) (from Pollack et al.
1998) with the stacked composite GSTH results for the Western Canada boreholes (A,B) (Majorowicz \& Safanda 1998a,b, Majorowicz et al. 1999). It can be observed that high-magnitude GST warming in the study area between late 19th century and 1990 significantly exceeds that of the globally averaged GST.

The GSTH curves for the whole study area (A), the northern boreal forest (boreholes north of $53.5^{\circ} \mathrm{N}$ ) (B), and the southern prairie grassland (boreholes south of $\left.53.5^{\circ} \mathrm{N}\right)(\mathrm{C})$ shown in Fig. 5 correlate well. The correlation between composite GSTH curves for the northern boreal and southern grassland is very high $(\mathrm{r}=0.98)$.

The average magnitude of warming, based on the data from the 43 sites, between the mid-19th century minimum and 1990 is slightly above $2^{\circ} \mathrm{C}$. The extended cold period lasting through the 17 th and 18th centuries attained its minimum in this region in the 19th century. The resolution of the GSTH rapidly decreases with time as a result of the diffusive character of heat conduction process (Clow 1992, Beltrami et al. 1995). It has a magnitude equivalent to $60 \%$ of the time since the occurrence of the identified event, i.e. the minimum we observe at AD 1860 (Fig. 5) can only be resolved to be between AD 1780 and 1940. 

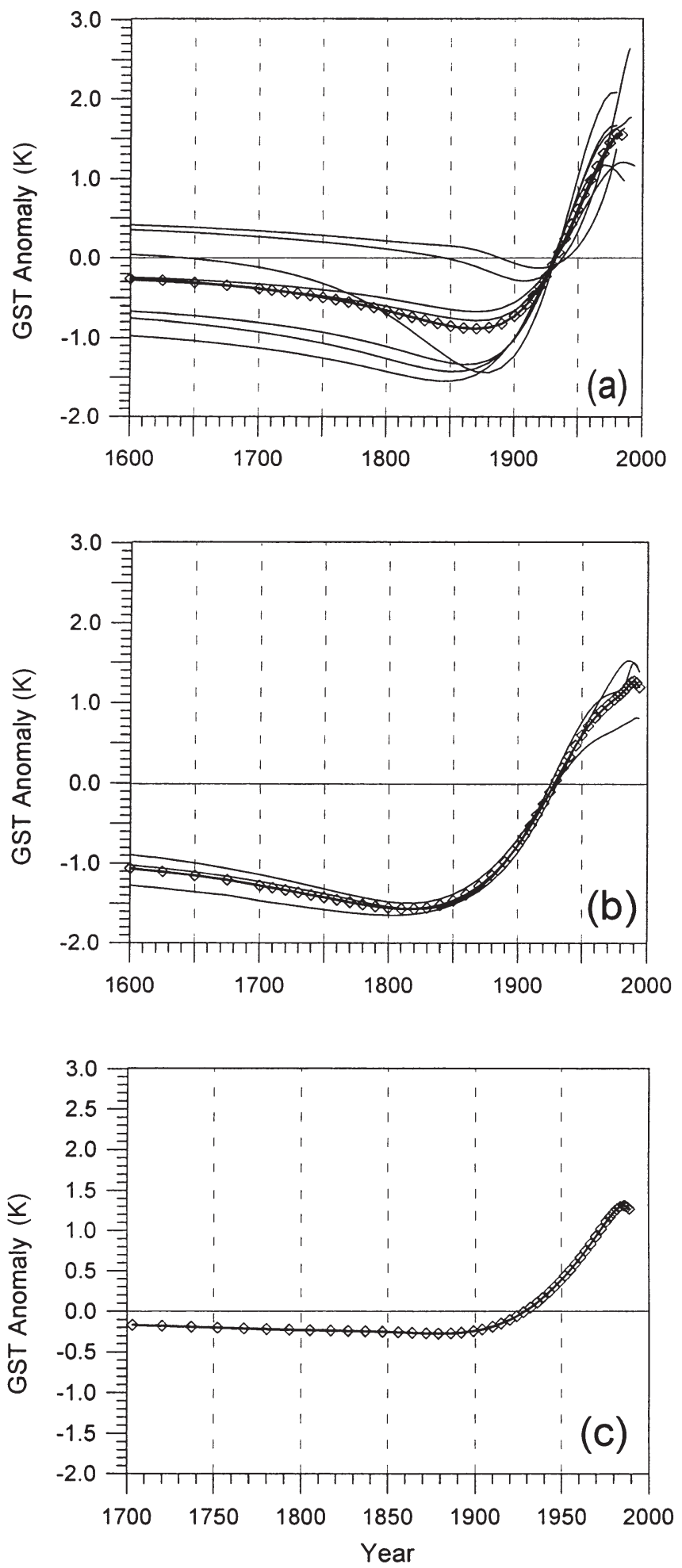

Fig. 3. Examples of GSTH (Majorowicz \& Safanda 1998a,b; Majorowicz et al. 1999) for 3 areas with multiple borehole logs: (a) Cold Lake Alberta/Saskatchewan border area (8 boreholes in boreal forest $<50 \mathrm{~km}$ radius); (b) Riverhurst in southern Saskatchewan (3 boreholes in grassland $<20 \mathrm{~km}$ radius); and (c) a simultaneous inversion of temperature logs in 5 boreholes at a single site $(<2 \mathrm{~km}$ radius $)$ in Alberta

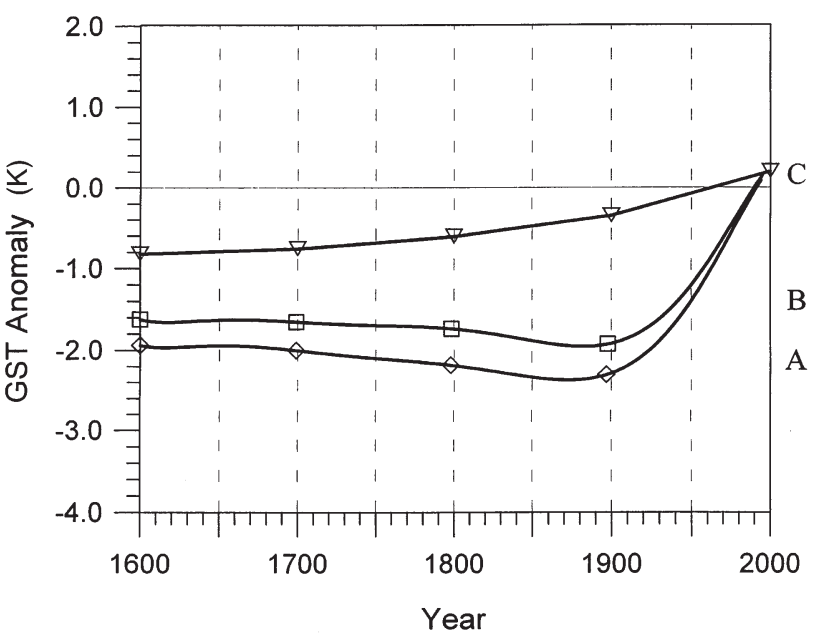

Fig. 4. Averaged GSTH results for Western Canada boreholes east of the Cordillera (A) and Prairie grassland (B) (Majorowicz \& Safanda 1998a,b, Majorowicz et al. 1999) compared with the global composite (average of 4 regions) GSTH curve (C) (Pollack et al. 1998). In order to compare A and B with $\mathrm{C}$, the anomalies were calculated relative to 1990 (as in Pollack et al. 1998)

\section{COMPARISON OF GSTH WITH OTHER PROXY METHODS}

The regional average GSTH curves (Fig. 5) were compared for the period 1600 to 1990 with the results of global- and hemispheric-scale temperature changes over the past 4 centuries based on multivariate highresolution proxy records as presented in Mann et al. (1998) and for the circum-Arctic from a compilation of paleoclimate records as presented in Overpeck et al. (1997). Because of the earth's filtering effect (Beltrami et al. 1995, Majorowicz \& Safanda 2001) the naturally smoothed GSTH results (loss of signal resolution with depth/time) were compared against filtered proxybased surface temperature change (Overpeck et al. 1997, Mann et al. 1998) for the circum-Arctic and for the northern hemisphere regions (Fig. 6). Our GSTH curves for western and northern Canada, shown in Fig. 5, correlate significantly $(\mathrm{r}>0.80)$ with Arctic annual temperature change (Fig. 7). However, the magnitude of the surface temperature change $\left(1.3^{\circ} \mathrm{C}\right)$ for the Arctic (circum-Arctic; Overpeck et al. 1997) is lower than that of the western and northern Canadian regional GSTHs $\left(>2.0^{\circ} \mathrm{C}\right)$. The magnitude of such change is even lower for the northern hemisphere annual temperature change over the last 4 centuries (Fig. 6). The relationship between the time series of regional western and northern Canadian GSTH for the entire study area and the filtered Arctic proxy surface temperature history (Overpeck et al. 1997) is good $(r>0.86)$ but far from linear. 


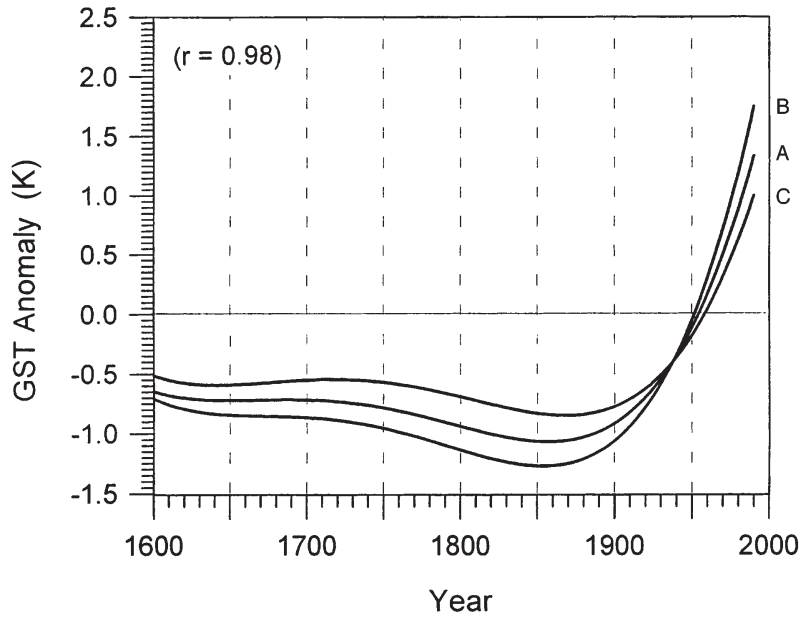

Fig. 5. Composite GSTH over the past 4 centuries, from temperatures in boreholes in the entire of the study area $(\mathrm{A})$, the northern boreal forest area (north of $\left.53.5^{\circ} \mathrm{N}\right)(\mathrm{B})$, the southern grassland area (south of $\left.53.5^{\circ} \mathrm{N}\right)(\mathrm{C})$. The statistical correlation between $\mathrm{B}$ and $\mathrm{C}$ is characterized by the correlation coefficient $r=0.98$

The closest northwestern Canada proxy data from Overpeck et al. (1997; sites 10 to 16) were taken from air temperature sensitive tree-ring chronologies from northern treeline sites (see Fig. 2 for site locations). The curves are reproduced in Fig. 8. Data for these sites were combined to obtain a combined proxy history for northwestern Canada immediately north of the majority of our boreholes. The combined proxy history and the western Canada GSTHs are also compared in

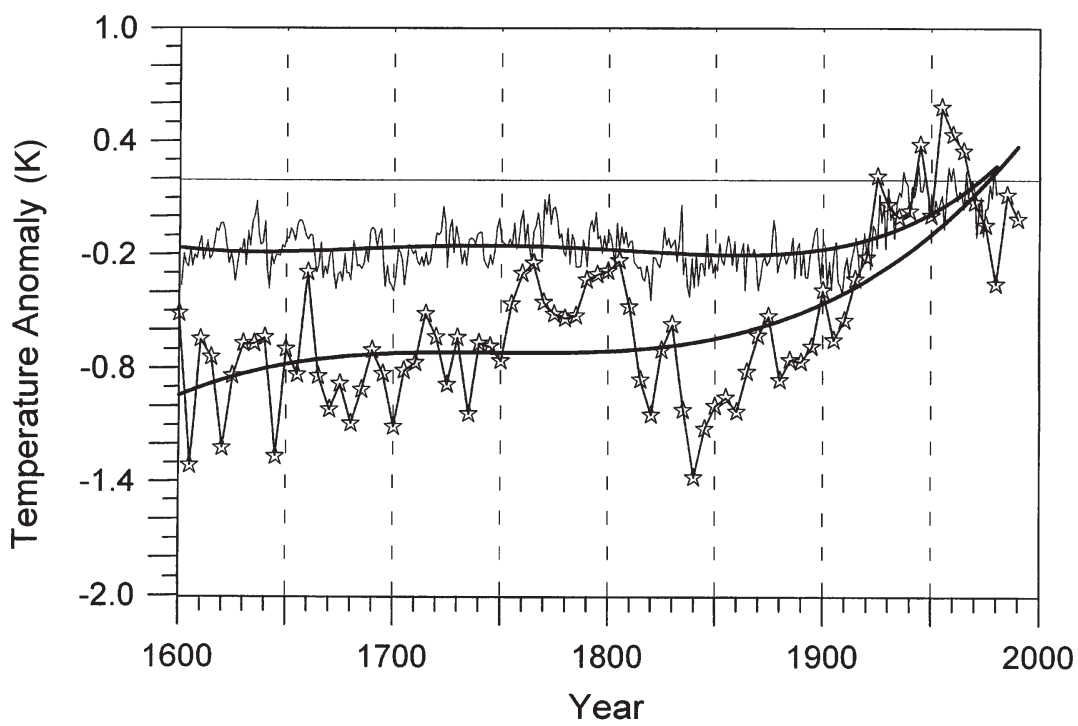

\section{Northern Hemisphere annual temperature}

Arctic-wide summer-weighted annual temperature

Fig. 6. Annual and filtered proxy temperature reconstructions for the last 4 centuries for the northern hemisphere (from Mann et al. 1998) and for the proxy Arctic-wide summer-weighted annual temperature (from Overpeck et al. 1997)

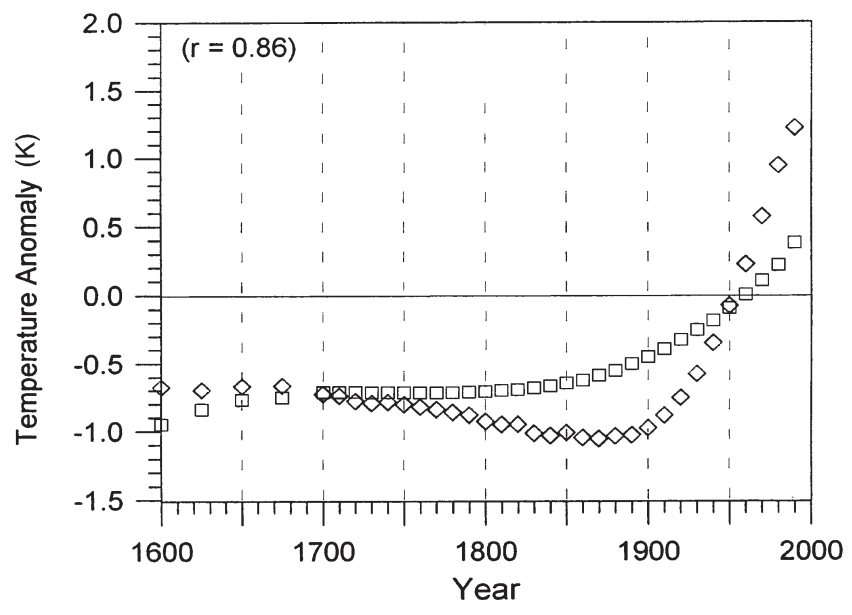

$\diamond$ Western Canada Ground Surface Temperature History

$\square$ Arctic-Wide Summer Weighted Annual Temparatures (Overpeck et al. 1997)

Fig. 7. Comparison between the time series of GSTH for the entire study area and the filtered Arctic proxy surface temperature history (Overpeck et al. 1997) $(r=0.86)$

Fig. 9. The statistical relationships are strong for both cases $(r=0.92)$.

A relationship was also found between the western Canada GSTH and proxy surface temperature reconstructions for 2 Alberta sites: summer temperature weighted tree-ring data from Columbia Icefield in the Canadian Rocky Mountains close to Athabasca Glacier (Luckman et al. 1997) (Fig. 10), and the Pine Lake median grain size record from sedimentological studies (Campbell et al. 1998). The prairie GSTH (Fig. 5, curve C) correlates strongly with other filtered series $(r>0.9)$. Fig. 10 also shows the HCN annual SAT time series averaged for 3 stations in closest proximity to the Columbia Icefield area (Banff, Jasper and Rocky Mountain House; see Fig. 1 for locations). The strongest correlation is between the prairie grassland GSTH curve and the tree-ring based surface summer temperature history $(r=0.95)$ (Fig. 11).

\section{DISCUSSION}

The average GSTH curve for the entire study area, as well as those for the 2 major sub-regions (northern boreal forest and prairie grassland) (Fig. 5), suggest that the observed warming in this century was preceded by an extended cold period lasting for 


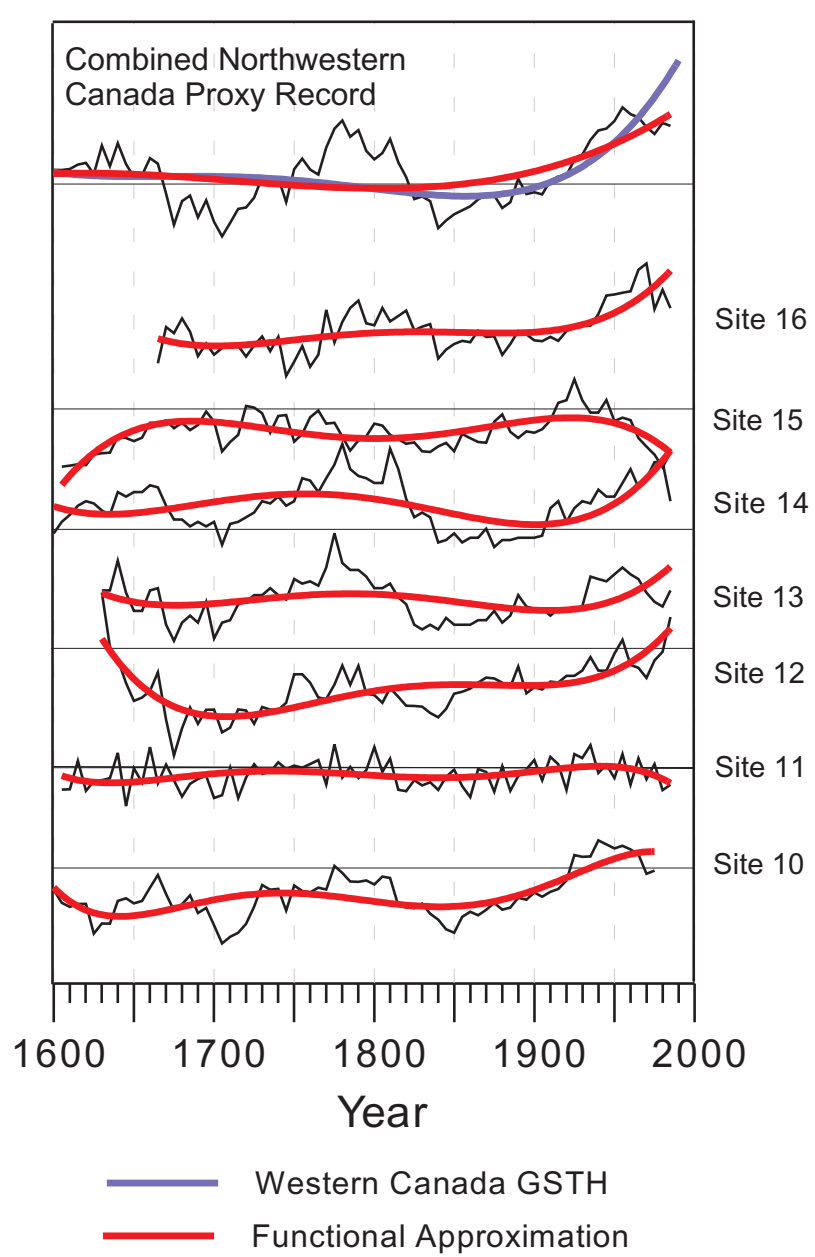

Fig. 8. Standardized 400 yr summer weighted proxy climate records from the 1901-1960 average with filtered curves for sites 10 to 16 in northwestern Canada (from Overpeck et al. 1997, Table 1). Note that the proxy climate records from each of these sites are based on tree-ring chronologies. The combined standardized proxy summer-weighted climate record reflecting surface air temperature (K) based on sites 10, 12, 13, 14 and 16 in northwestern Canada is compared against the Western Canada GSTH curve

over 2 centuries which reached a minimum in the midto late 19th century. Recently, a northern hemisphere, millennium-scale cooling trend consistent with astronomical forcing has been identified from proxy networks (Mann \& Bradley 1999). Despite the fact that such reconstructions are heavily based on tree-ring data usually standardized with different and arbitrary functions removing growing trends for each tree used to create the chronology, the observed GSTH in western and Northwestern Canada fits Mann \& Bradley's (1999) hemispheric scheme well. It identifies warming after a lengthy cold period that had persisted for over 2 centuries. In this context, the latter conclusion is based

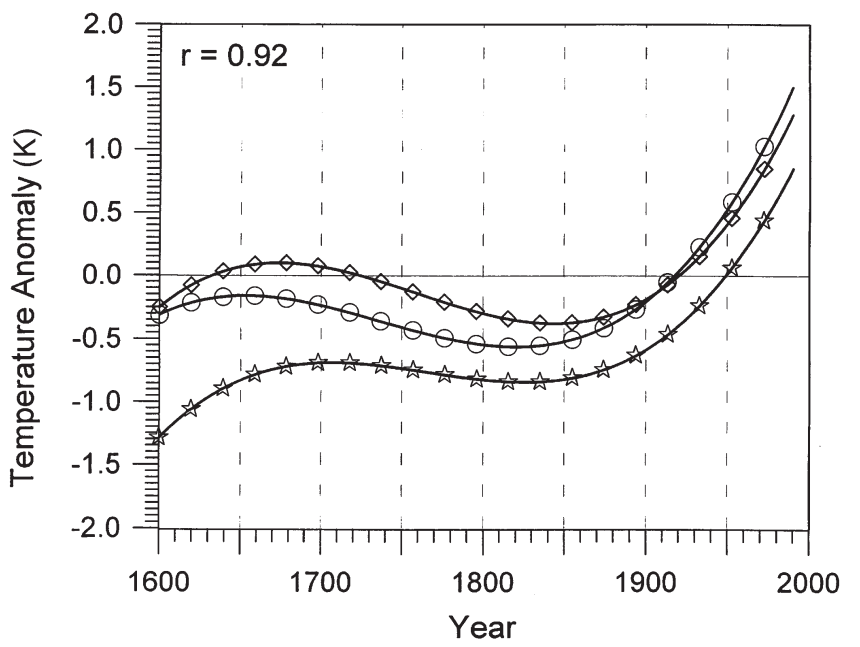

C Combined NW Canada temperature anomalies (Overpeck et al., 1997)

- GSTH for entire study region

$\diamond$ GSTH for southern prairie grassland

Fig. 9. Comparison between GSTH anomalies for the whole of the study area (Fig. 5, curve A), the combined proxy northwestern Canada summer-weighted annual temperature anomalies relative to the 1901-1960 level (from Fig. 8) ( $\mathrm{r}=0.92)$, and the southern prairie grassland GSTH (Fig. 5, curve C)

on the spatial consistency of the GST warming as derived from the temperature logs from boreholes of 43 sites spread over a large territory of western and northern Canada between 49 and $68^{\circ} \mathrm{N}$, east of the Cordillera (Rocky Mountains).

The above result is similar to surface temperature histories derived from other proxy methods for the Arctic Islands (Beltrami \& Taylor 1995), the circumArctic (Overpeck et al. 1997), the northern hemisphere (Mann et al. 1998), the Rocky Mountains (Luckman et al. 1997) and the Foreland Basin (Campbell et al. 1998). It also coincides with the GSTHs derived from borehole temperatures and tree-ring data from eastern Canada (Beltrami et al. 1995). Such corroborating evidence strongly suggests a large-scale decade-tocentury-scale variability in common to widely separated and diverse climate regions.

The recovery from these cold periods coincides in a large part with the onset of the anthropogenic landcover changes, which began in the early to mid-19th century in eastern Canada (southern Ontario; Lewis \& Wang 1998), and early 20th century in Western Canada (Majorowicz \& Skinner 1997b, Skinner \& Majorowicz 1999). These changes, when superimposed upon larger-scale climate warming, are the probable cause of the excessively large magnitudes of GST warming in some areas (especially in central Alberta).

The correlation of Arctic climate proxy tree-ring records from the northern Canada treeline with mainly 
Fig. 10. Comparison of tree-ring-data-based temperature anomalies (from Luckman et al. 1997), the HCN annual SAT time series averaged for 3 stations from the southern Alberta foothill in closest proximity to the Columbia Icefield area (Banff, Jasper and Rocky Mountain House) and Prairie grassland GSTH

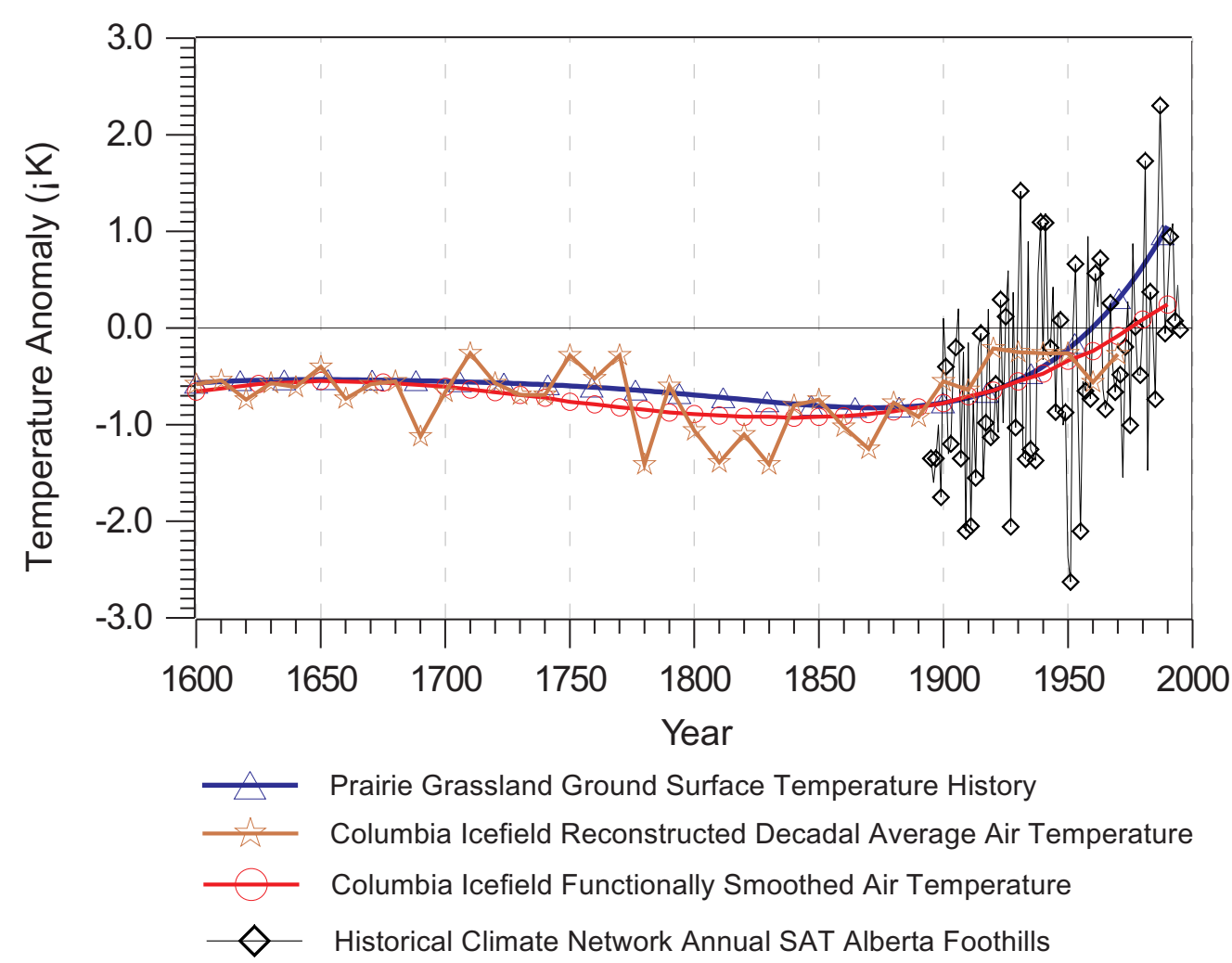

grassland boreholes located far to the south proves that a large-scale climate history is common to both regions and that land-cover changes and other disturbances overlie this. The GSTH relationship to other northern and western Canadian proxy climate records is strong, although GSTH changes derived from borehole temperatures are of much larger magnitude. All records

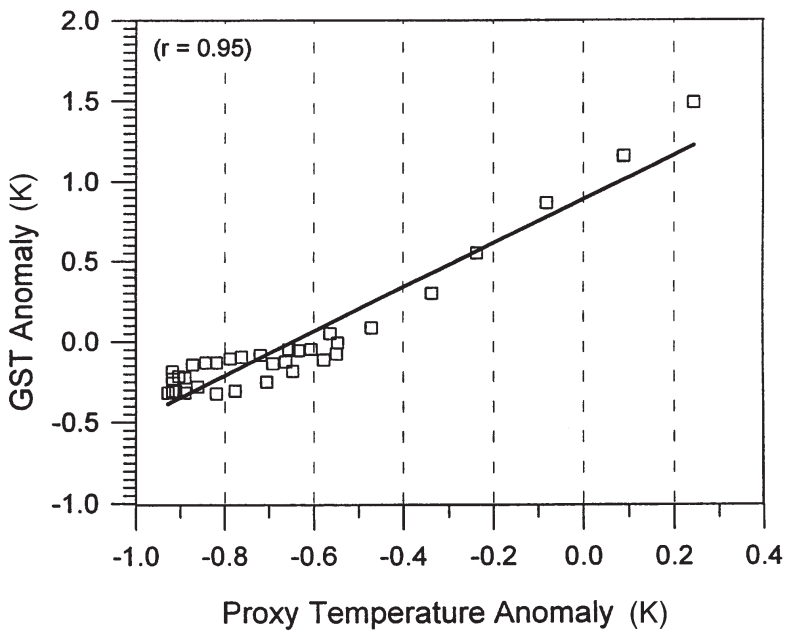

Fig. 11. Linear function approximation of the statistical relationship between GSTH for the boreholes in the Prairie grasslands and tree-ring-based surface temperature history of Luckman et al. (1997) $(\mathrm{r}=0.95)$ show strong relationships with northern hemisphere variability. This suggests a possible dependence of the western and northwestern Canada climate on largescale Pacific and tropical Pacific forcings on both interannual and interdecadal temporal scales.

Decadal-to-century-scale GST variability in this region is similar to that of the northern hemisphere. These findings strongly suggest that the similar, but enhanced, temperature signal identified by GSTHs make this a robust indicator region of global change. Large regional GSTHs prove extremely useful in crosschecking the credibility of century-scale proxy reconstructions and providing inference of past climate variations in a region with sparse proxy climate data coverage. Unlike tree-ring data, which needs to be calibrated versus SAT data, they provide a direct measure of the warming/cooling magnitude.

\section{SUMMARY}

Inversions of the temperature profiles in boreholes of 43 sites throughout western and northwestern Canada east of the Rocky Mountains were used to reconstruct past ground surface temperature (GST) conditions over several centuries on decadal-to-century time scales. There is evidence of extensive recent warming which has exceeded that of globally averaged GST 
between the mid-19th century and 1990, following a lengthy cold period that had persisted for several centuries. Strong statistical relationships are found between the ground surface temperature histories (GSTHs) of western Canada and, when filtered, other published higher temporal resolution proxy climate histories, for the northern hemisphere (Mann et al. 1998) and for the Canadian Arctic (Overpeck et al. 1997). Despite the problems with both types of methods (Beltrami \& Mareschal 1995, Briffa 2000), such as the use of arbitrary functions to remove growth trends and changes in response of tree growth to temperature in time in the tree-ring method and a sharp decrease of temporal resolution of GST back in time and an influence of the surface changes in the geothermal method, the correlation between the two is remarkably high.

Strong correlation also exists between the prairie grassland GSTH and the filtered tree-ring-based surface summer temperature history from Columbia Icefield in the Canadian Rocky Mountains close to Athabasca Glacier (Luckman et al. 1997). The strong relationship between the tree-ring-based proxy series, which is related to growing season temperatures, and the borehole series is encouraging. The 20th century warming is evident over a large region of western and northwestern Canada, and the signal at the ground surface appears during the spring thaw to fall freeze period, when penetration of sensible heat to the subsurface is most active.

The decadal-to-century-scale climate of western and northwestern Canada appears linked to large-scale Pacific and tropical Pacific processes as well as those of the northern hemisphere. These suggest that the similar, but enhanced, SAT warming signal identified by GSTH make this a strong indicator region of global change. Large region GSTHs prove extremely useful in improving the credibility of decade-to-century-scale proxy reconstructions and providing inference of past climate variations in a region having sparse proxy climate data coverage.

Acknowledgements. The authors acknowledge the helpful comments of Dr Hugo Beltrami and 2 other anonymous reviewers on the earlier version of this paper. Cooperation of Dr Jan Safanda on the earlier papers which have led to this one is greatly appreciated. J.A.M. acknowledges the help of Environment Canada and Canadian IGCP 428 project.

\section{LITERATURE CITED}

Beach RWW, Jones FW, Majorowicz JA (1987) Heat flow and heat generation estimated from Churchil basement of the Western Canada Basin, Canada, Geothermics 16:1-16

Beltrami H, Mareschal JC (1995) Resolution of ground temperature histories inverted from borehole temperature data. Global Planet Change 11:127-138
Beltrami H, Taylor AE (1995) Records of climatic change in the Canadian Arctic: towards calibrating oxygen isotope data with geothermal data. Global Planet Change 11: 57-70

Beltrami H, Jessop AM, Mareschal JC (1992) Ground temperature histories in eastern and central Canada from geothermal measurements; evidence of climatic change. Global Planet Change 6:167-184

Beltrami H, Chapman DS, Archambault S, Bergeron Y (1995) Reconstruction of high resolution ground temperature histories combining dendrochronological and geothermal data. Earth Planet Sci Lett 136:437-445

Briffa KR (2000) Annual climate variability in the Holocene: interpreting the message of ancient trees. Q Sci Rev 19: 87-105

Campbell ID, Campbell C, Apps MJ, Rutter NW, Bush AB (1998) Late Holocene-1500 year climatic periodicities and their implications. Geology 26(5):471-473

Clow GD (1992) The extent of temporal smearing in surface temperature histories derived from borehole temperature measurements. Global Planet Change 98:81-86

Gosnold WD, Todhunter PE, Schmidt W (1997) The borehole temperature record of climate warming in the mid-continent of north America. Global Planet Change 15:33-45

Guillou-Frottier L, Mareshal JC, Musset J (1998) Ground surface temperature history in central Canada inferred from 10 selected borehole temperature profiles. J Geophys Res 103:7385-7397

Harris RN, Chapman DS (1998) Geothermics and climate change, 1 . Analysis of borehole temperatures with emphasis on resolving power. J Geophys Res 103:7363-7370

IPCC (1996) Climate change 1995: the science of climate change. Houghton JT, Meira Filho LG, Callander BA, Harris N, Kattenberg A, Maskell K (eds) Cambridge University Press, Cambridge

Jessop AM (1990) Thermal geophysics, developments in solid earth geophysics 17. Elsevier, Amsterdam

Lachenbruch AH, Marshall BV (1986) Changing climate: geothermal evidence from permafrost in the Alaskan Arctic. Science 234:689-696

Lewis TJ, Wang K (1998) Geothermal evidence for deforestation induced warming: implications for the climatic impact of land development. Geophys Res Lett 25:535-538

Luckman BH, Briffa KR, Jones PD, Schweingruber FH (1997) Tree-ring based reconstruction of summer temperatures at the Columbia Icefield, Alberta, Canada, AD 1073-1983. The Holocene 7(4):375-389

Majorowicz JA (1993) Climate change inferred from analysis of borehole temperatures: first results from Alberta, western Canada. Pure Appl Geophys 140:87-100

Majorowicz JA, Safanda J (1988a) GST history from inversions of underground temperatures - case study. Tectonophys 291:287-298

Majorowicz JA, Safanda J (1988b) Is the climatic warming magnitude underestimated? - Analysis of climate change signals stored below the surface from the borehole temperature measurements in the Canadian Prairies. In: Bunterbarth G (ed) Microtemperature signals of the earth's crust. 192 Seminar (WE-Heraeus-Stiftung), Paperflieger, Clausthal-Zellerfeld, p 68-78

Majorowicz JA, Safanda J (2001) Composite surface temperature history from inversions of borehole temperatures in the Canadian Grasslands. Beltrami H, Harris R (eds) Global Planet Change Spec Iss (in press)

Majorowicz JA, Skinner WR (1997a) Anomalous ground warming versus surface air warming in the Canadian Prairie Provinces. Clim Change 35:485-500 
Majorowicz JA, Skinner WR (1997b) Potential causes of differences between ground and surface air temperature warming across different ecozones in Alberta, Canada. Global Planet Change 315:79-91

Majorowicz JA, Safanda J, Harris R, Skinner WR (1999) Large ground surface temperature changes of the last three centuries inferred from borehole temperatures in the southern Canadian prairies-Saskatchewan. Global Planet Change 20:227-241

Mann ME, Bradley RS (1999) Northern Hemisphere temperatures during the past millennium: inferences, uncertainties, and limitations. Geophys Res Lett 26(6):759-762

Mann ME, Bradley RS, Hughes M (1998) Global scale temperature patterns and climate forcing over the past six centuries. Science 392:779-787

Overpeck J and 17 others (1997) Arctic environmental change of the last four centuries. Science 278:1251-1256

Pollack HN, Shen PY, Huang S (1996) Inference of ground surface temperature history from subsurface temperature data: interpreting ensembles of borehole logs. Pure Appl Geophys 147:537-550

Pollack HN, Huang S, Shen PY (1998) Climate change record in subsurface temperatures: a global perspective. Science 282:279-281

Shen PY, Beck AE (1991) Least squares inversion of borehole temperature measurements in functional space. J Geophys Res 96:19965-19979

Editorial responsibility: Brent Yarnal,

University Park, Pennsylvania, USA
Shen PY, Pollack HN, Huang S, Wang K (1995) Effects of subsurface heterogeneity on the inference of climatic change from borehole temperature data: model studies and field examples from Canada. J Geophys Res 100(B4):6383-6396

Shen PY, Pollack HN, Shaopeng H (1996) Inference of ground surface temperature history from borehole temperature data: a comparison of two inverse methods. Global Planet Change 14:49-57

Skinner WR, Majorowicz JA (1999) Regional climatic warming and associated twentieth century land-cover changes in north-western North America. Clim Res 12:39-52

Taylor AE, Burgess M, Judge A, Allen VS (1982) Canadian Geothermal Data Collection-Northern Wells 1981, Geothermal Series, Earth Physics Branch, Energy Mines Resources Canada, Ottawa

Vincent L (1998) A technique for the identification of inhomogeneities in Canadian temperature series. J Clim 11: 1094-1104

Vincent L, Gullett DW (2001) Creation of historic and homogeneous datasets for climate change analyses in Canada. Int J Climatol (in press)

Wang K, Lewis TJ, Jessop AM (1992) Climatic changes in central and eastern Canada inferred from deep borehole temperature data. Global Planet Change 6:129-142

Zhang X, Vincent LA, Hogg WD, Niitsoo A (2000) Temperature and precipitation trends in Canada during the 20th century. Atmos Ocean 38:395-429

Submitted: October 6, 1999; Accepted: June 5, 2000 Proofs received from author(s): January 2, 2001 
